\title{
The influence of aquatic macrophytes on the distribution and feeding habits of two Asplanchna species (A. priodonta and $A$. herrickii) in shallow wetlands in South Korea
}

\author{
Jong-Yun CHOI, ${ }^{1}$ Kwang-Seuk JEONG, ${ }^{2}$ Geung-Hwan LA, ${ }^{3}$ Kwang-Hyeon CHANG, ${ }^{4}$ Gea-Jae JOO ${ }^{2 *}$ \\ ${ }^{1}$ National Institute of Ecology, Seo-Cheon Gun, Chungcheongnam province 325-813, South Korea; ${ }^{2}$ Department of Biological Sciences, \\ Pusan National University, Busan 609-735, South Korea; ${ }^{3}$ Department of Environmental Education, Sunchon National \\ University, Suncheon, Jeonnam 540-742, South Korea; ${ }^{4}$ Dept of Environmental Science and Engineering, Kyung-Hee University, \\ Yongin, Gyeonggi 446-701, South Korea \\ *Corresponding author: gjjoo@pusan.ac.kr
}

\begin{abstract}
We tested the hypothesis that the spatial distribution and diet composition of Asplanchna species might be affected by the presence of aquatic macrophytes in 33 wetlands in South Korea. We estimated the densities of Asplanchna and other rotifer and crustacean, together with environmental parameters, in both vegetated and open water zones, from May to June 2011. In the present study, two species of Asplanchna, A. priodonta and A. herrickii, were observed and significantly more abundant in open water zones lacking macrophytes. In particular, the density of A. priodonta was higher than that of A. herrickii, and the density of A. priodonta was strongly positively correlated with the area of open water. In addition, gut content analysis was used to determine their dietary preferences, with the finding that there was apparent differentiation in food source utilisation between the two Asplanchna species; A. priodonta consumed some protozoa, phytoplankton, and exclusively pelagic rotifer, while A. herrickii consumed primarily Euglena. In particular, Keratella and Polyarthra were most commonly consumed by A. priodonta in open water. Macrophytes represent a suitable habitat for epiphytic rotifer but not for pelagic rotifer; this characteristic drives pelagic rotifer such as Asplanchna towards open water and may be responsible for the significant negative correlation that we observed between macrophyte and Asplanchna densities.
\end{abstract}

Key words: Aquatic macrophytes, Asplanchna, diet composition, freshwater wetlands, rotifer distribution.

Received: October 2013. Accepted: May 2014.

\section{INTRODUCTION}

Freshwater macrophytes are one of the fundamental factors that influence the structure of freshwater ecosystems. Physically, macrophytes exert dramatic effects by participating in the construction of heterogeneous mosaics on different scales (O'Hare et al., 2006; Kuczynska-Kippen, 2007). The habitat heterogeneity hypothesis (Simpson, 1949; Lack, 1969) assumes that structurally complex habitats provide an increased availability of niches for resident animals and encourage diversity in exploiting environmental resources; this finally results in increased species diversity.

Some studies have suggested that macrophyte habitat structure mediates trophic interactions among various biological factors (Jeppesen et al., 1997; Pelicice and Agostinho, 2006), an aspect that has attracted interest regarding the role of macrophytes in determining predatorprey interactions. Macrophytes are commonly utilised as habitats or refuges for prey in freshwater ecosystems. In particular, the role of macrophytes in mediating zooplankton dynamics is well understood in freshwater ecosystems (Cazzanelli et al., 2008; Horppila et al., 2009). Furthermore, various predator-prey interactions, including those between fish and zooplankton (mainly cladocerans and copepods), have been investigated within macrophyte habitats. Moreover, rotifer dynamics can be explained by predator-prey interactions within rotifer groups in macrophyte habitats. Because rotifer play a fundamental role (i.e., as primary consumer) in determining food web structures and functions, examining this relationship will improve our understanding of the patterns of rotifer biological diversity in relation to macrophyte density. Even though previous research has examined Asplanchna, a predatory rotifer species, in terms of its dynamics and the role that habitat plays in freshwater ecosystems, the predator-prey interactions within the rotifer community related to habitat heterogeneity has not been addressed.

Asplanchna is a typical omnivore that consumes phytoplankton, detritus, and rotifer (Thatcher et al., 1993). Species of this genus are one of the most voracious rotifer predators, often cannibalistic, and are capable of feeding on nearly all species of the family Brachinidae as well as other rotifer (Gilbert, 1980). Interestingly, Asplanchna species exhibit different dietary preferences, and consequently have different prey preferences. Asplanchna priodonta is known as typically omnivorous, but it often 
prefers colonial algae and even cyanobacteria over zooplankton prey (Pociecha and Wilk-Woznisk, 2008). On the contrary, Asplanchna herrickii is a detritivore (Chang et al., 2010). Temporal variations in Asplanchna, including interannual or seasonal dynamics (Ortega-Mayagoitia et al., 2000; Havel et al., 2004), have demonstrated that various habitat environments and types/size of prey and predators influence its feeding strategies (Guiset, 1977; Nandini et al., 2003). Furthermore, hydrological stability (i.e., a relatively long water residence time) is also an important factor determining the density and feeding of Asplanchna (Ferrari et al., 1989). Among freshwater ecosystems, wetlands are relatively stable and provide structural heterogeneity conferred by macrophytes. Therefore, they are a suitable system for understanding the influence of macrophytes on the distribution and feeding habits of Asplanchna. Previous research on Asplanchna spp. has primarily focused on their population dynamics or on the basic characteristics of their feeding habits. On the other hand, the relationships between the feeding patterns of Asplanchna species and the characteristics of their surrounding habitats, with reference to predator-prey interactions, have not been fully scrutinised.

In this study, we examined 33 wetland ecosystems to understand the relationship between aquatic macrophytes, prey rotifer, and predation by Asplanchna spp. on other rotifer. We hypothesised that the presence of aquatic macrophytes would have a negative impact on $A s$ planchna predation and might affect the diversity and density of prey rotifer. In addition, we also hypothesised that i) aquatic macrophytes determine the distribution patterns of Asplanchna in wetland ecosystems; ii) prey rotifer (pelagic and epiphytic) in wetlands present different patterns between vegetated and open water zones because of the unequal densities of predators (i.e., Asplanchna); and iii) density changes in prey rotifer cause a shift in the food selection patterns of Asplanchna spp.

\section{METHODS}

\section{Study site}

South Korea is located in the East Asian region, and has a temperate climate with four distinct seasons. The annual average rainfall is approximately $1150 \mathrm{~mm}$; freshwater ecosystems in this country experience a summer maximum in rainfall (more than $60 \%$ of annual rainfall occurs from June to early September; Jeong et al., 2007). The wetlands monitored in this study are located in south-eastern Korea, within the central and lower reaches of the Nakdong River. Historically, numerous riverine wetlands dominated the river basin, but urbanisation has led to a reduction in the area and number of wetlands; this has also been observed in other countries (Burkett and Kusler, 2000).

Currently, 146 wetlands are present in the river basin and this study selected 33 of them. We used two selection criteria to analyse Asplanchna predation in relation to macrophytes: i) the average depths of the study sites should be broadly similar; and ii) zones of vegetated water and open water should be simultaneously present. Consequently, we selected 33 wetlands in the river basin for analysis (Fig. 1; Supplementary Tab. 1). The areas of the studied wetlands varied from 1321 to $5234 \mathrm{~m}^{2}$, most of which were being utilised for agricultural water supply at the time this study was conducted. Littoral zones were shallow (depths ranging from 0.5 to $0.8 \mathrm{~m}$ ), but central areas were deeper (depths ranging from 1.2 to $1.6 \mathrm{~m}$ ), resulting in a clear littoral zonation of aquatic macrophyte development (abundant only in littoral zones). Altogether, five aquatic macrophytes were commonly observed at the study sites, namely, Phragmites australis (Cav.), Paspalum distichum L., Zizania latifolia Griseb., Trapa japonica Flerov., and Scirpus tabernaemontani Gmel., all of which were abundant in the littoral area only.

\section{Monitoring strategy}

We surveyed the wetlands from late May to early June 2011 (over a period of two weeks), before the occurrence of the summer monsoon. This was to avoid any disturbance of the distribution of aquatic macrophytes. We established six sampling points in each of the 33 wetlands to collect water samples: three points were in vegetated zones and three were in open water zones. The sampling points were randomly selected based on virtual grids constructed over the maps of the wetlands.

Water temperature, dissolved oxygen, conductivity, turbidity, and chlorophyll $a$ concentration were measured at each of the wetlands. Water samples were collected at a depth of $0.5 \mathrm{~m}$ in both the vegetated and open water zones. We used a DO meter (YSI DO meter; Model 58) to measure water temperature and dissolved oxygen; conductivity was measured using a conductivity meter (Fisher Conductivity Meter; model 152). Turbidity was measured using a turbidimeter (Model 100B). Water samples were filtered through a Mixed Cellulose Ester (MCE) membrane filter (Advantech; Model No., A045A047A; pore size, $0.45 \mu \mathrm{m}$ ), and chlorophyll $a$ concentration was measured based on Wetzel and Likens (2000). The area of open water was measured using a Geographic Information Systems (GIS) program (ArcGIS 9.3) and a digital map (National Geographic Information Institute, 2005; 1:25,000). Additionally, we sampled an additional $10 \mathrm{~L}$ of water for zooplankton (rotifer, cladoceran, and copepod) collection from the surface layer (0-0.5 m depth), using a $10 \mathrm{~L}$ column sampler. This water was filtered through a plankton net (32- $\mu \mathrm{m}$ mesh size) for estimating the density of plankton, after which the plankton were preserved in formaldehyde (final concentration: ca. 5\%). The zooplankton were identified and counted at genus level using a microscope (ZEISS, Model Axioskop 40; 200× magnification), based 
on the classification key supplied by Mizuno and Takahashi (1999).

One of the goals of this study was to compare the food preferences of Asplanchna species. Therefore, we classified potential prey rotifers into two habitat groups, pelagic and epiphytic, according to Sakuma et al. (2002), Gyllström et al. (2005) and Choi et al. (2012). Supplementary Tab. 2 summarizes the information about the habitat groups based on the aforementioned references. We applied the following criteria: i) if a genus is identified as either pelagic (the term planktonic was replaced with pelagic in the current version) or epiphytic in all three references, then the genus was identified as is; ii) if a genus is differently identified (e.g., one reference indicate the genus as pelagic, but the others do as epiphytic; or more than one reference indicates the genus as ambiguous), then we identified the genus as ambiguous.

For Asplanchna diet analysis, commercial bleach (ca. $0.2 \mathrm{~mL}$; containing sodium hypochlorite) was added to suspensions of isolated Asplanchna individuals to extract their trophi and gut contents and to dissolve the organic matter attached to their body surfaces (Schoeneck et al., 1990). The treatment with bleach enabled us to extract the trophi of Asplanchna as well as remains from prey items (such as other rotifer, phytoplankton and protozoa). Among organs or tissues of living things, hard chitinous structures can remain for a longer time when bleach is treated, but the other soft tissues may be dissolved quickly. Therefore, we applied bleach to the samples following suggestion from Chang et al. (2010), under very careful consideration not allowing complete dissolution of samples (empirically, sample identification should be completed within 30 to $120 \mathrm{~s}$ after bleach treatment; more than 180 s may cause loss of samples; Kwang-Hyeon Chang, personal communication). We conducted gut analysis of all Asplanchna individuals collected from each wetland, and all of the prey found in the guts were identified and quantified. Identification of the trophi of both
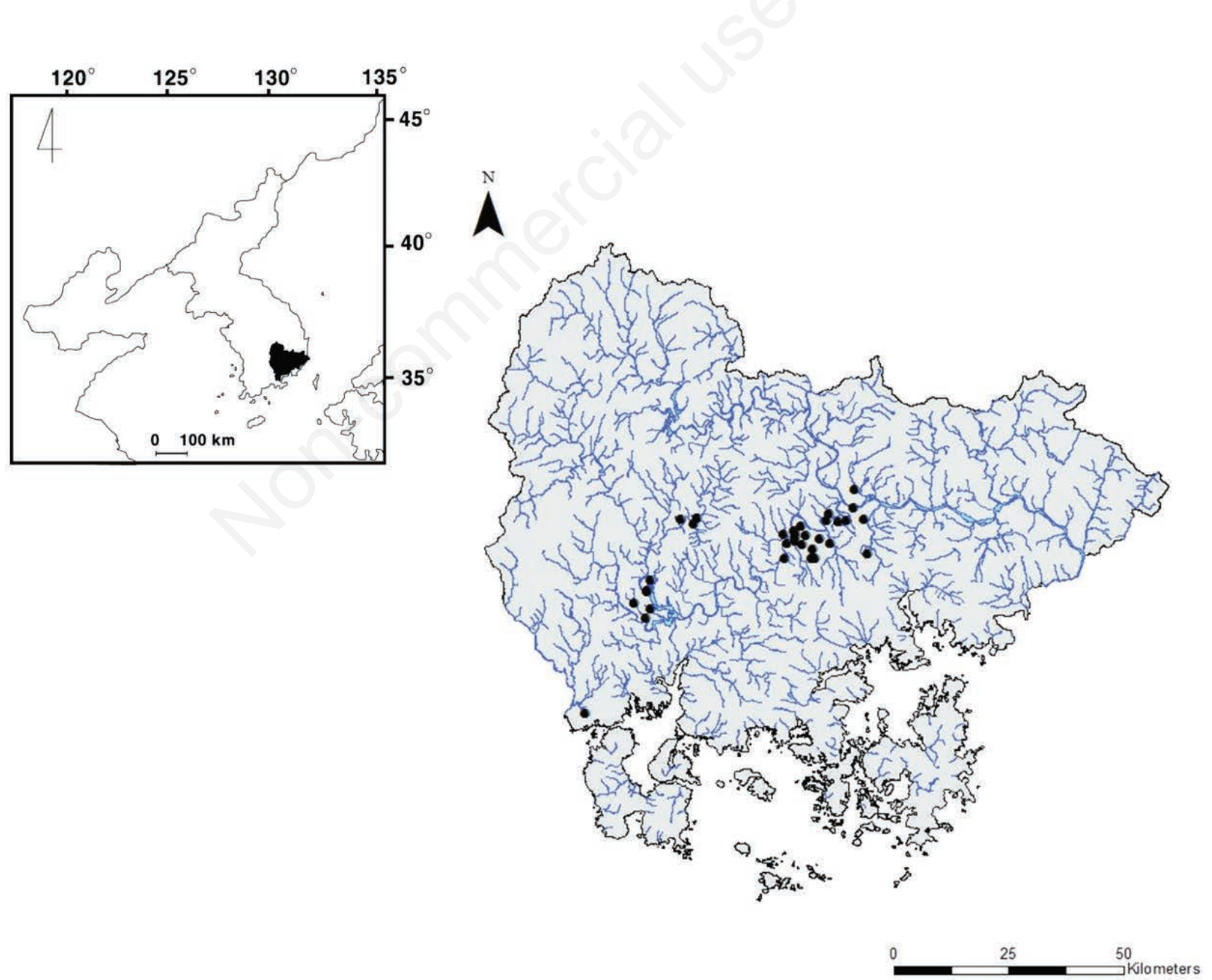

Fig. 1. Map of the study area in south-eastern South Korea. The study sites are indicated as solid circles $(\bullet)$. The small map in the upper left corner indicates the Korean Peninsula. 
Asplanchna and prey rotifer was done according to Jersabek et al. (2003). Prey phytoplankton and protozoa in Asplanchna guts were identified to the genus level based on Yamaji (1991).

\section{Data analysis}

We used one-way nested ANOVA $(\alpha=0.05)$ to analyse statistical differences of environmental parameters, densities of two Asplanchna species, and other rotifers (both pelagic and epiphytic), between vegetated and open water zones. As we established three sampling points for each zone in each wetland, direct application of one-way nested ANOVA may cause pseudoreplication problem (i.e., data homogeneity between sampling points should be ensured; Hurlbert, 1984). Therefore we set the two zones as the primary factor and the three replication (i.e., sampling points) were regarded as nested subgroups for each zone. For the environmental parameters, total 99 samples per zone was obtained ( 33 wetlands $\times 3$ sampling points $=99$ samples; 99 samples $\times 2$ zones=total 198 samples). Furthermore, the relationship between the density of $A$, priodonta species and environmental variables were tested with stepwise multiple regression. All statistical analyses, including stepwise multiple regression and ANOVA, were conducted using the statistical package SPSS for Windows ver. 14). In order to assess prey selectivity, we compared the relative frequencies of rotifers in the water samples with those in Asplanchna guts.

Regression analysis was used to examine the following relationships: i) area of vegetated and open water zones in the studied wetlands and the distribution of $A$. priodonta in these zones; ii) density of Asplanchna and prey rotifers (i.e., pelagic and epiphytic rotifers, respectively; genus identified as ambiguous were not included in the analysis); and iii) counted prey rotifers in $A s-$ planchna guts and density in water samples. We tested for linear, exponential, inverse, power, and logistic functions, to determine an equation generating the best curve fit. Among the regression results, the curve-fitting equation that returned the highest determination coefficient was selected to explain the observed relationships. For the regression analysis investigating relationship between density of Asplanchna and prey rotifers, we used sum of sample data (density of zooplankton) that were obtained from three sampling points in open water zone, to avoid pseudoreplication problem. Moreover, not only the regression analysis aforementioned but also stepwise multiple regression utilized only data from the wetlands with presence of Asplanchna.

\section{RESULTS}

The monitored parameters showed little difference between the two studied zones (i.e., vegetated and open water zones) among the 33 wetlands (Tab. 1; Supplementary Tab. 1). In result of one-way nested ANOVA analysis (Tab. 2), the environmental parameters were not significantly different between the two zones. Subgroups (i.e., three sampling points) for all of the environmental parameters also did not show statistical difference.

Two Asplanchna species, A. priodonta and A. herrickii, were identified in the wetlands, found in total 18 wetlands among 33 wetlands. Asplanchna priodonta was observed in all wetlands where Asplanchna appeared, whereas $A$. herrickii co-occurred with $A$. priodonta in only three wetlands among 18 wetlands. When those 18 wetlands were used in the one-way nested ANOVA to figure out the distribution pattern of $A$. priodonta, a clear difference of distribution was observed. Even though, Asplanchna priodonta were found in both vegetated- and open water zones, they were more abundant in open water zones than vegetated zones based on homogeneous distribution between sampling points (Tabs. 1 and 2). In contrast, $A$. herrickii was observed in only open water zones. Rotifers were observed in all of the investigated wetlands, and density of rotifer was clearly different between vegetated zones and open water zones (Tabs. 1 and 2). The density of pelagic rotifers was not different between the two zones, but epiphytic rotifer densities were significantly different (Tab. 2). No statistical difference was found between sampling points. Vegetated zones supported not only pelagic rotifers but also epiphytic rotifers. In open water, the rotifer species composition was dominated by pelagic types such as Keratella and Polyarthra, but other genera such as Anuraeopsis, Ascomorpha, Filinia, and Kelicottia, also known as pelagic type rotifers, were less abundant. Cladocerans and copepods were detected in most of the investigated wetlands, but their densities were lower than those of rotifers (Tab. 1).

The result of the stepwise multiple regression allowed us to examine the influence of environmental parameters on the density and distribution of $A$. priodonta (Tab. 3; $A$. herrickii was not included in the analysis due to very low density). Form the observation, Asplanchna species were found only from open water zones, therefore stepwise multiple regression was applied to the Asplanchna data of the open water zones. The total density of $A$. priodonta displayed strong relationship with the area of open water zones and the density of pelagic rotifers $\left(r^{2}=0.907\right.$, d.f. for regression, residuals, and total $=2,29$, and 32 , respectively; $F=91.44, \mathrm{P}=0.001$; Tab. 3 for independent variables). The correlation value between $A$. priodonta and the area of open water was particularly strong and show a positive relationship between $A$. priodonta density and the area of open water (Fig. 2). Relatively similar density of $A$. priodonta between vegetated zones of the wetlands would cause statistical insignificance. Analysis of the gut contents of 317 individuals of Asplanchna (A. priodonta, 
Tab. 1. Mean, standard deviation, standard error, and range in zooplankton density and environmental parameters, across the selected study sites. The unit of zooplankton density is ind. $\mathrm{L}^{-1}$.

\begin{tabular}{|c|c|c|c|c|c|c|c|}
\hline \multirow[t]{2}{*}{ Type } & \multirow[t]{2}{*}{ Variable } & \multicolumn{3}{|c|}{ Vegetated zones } & \multicolumn{3}{|c|}{ Open water zones } \\
\hline & & Mean \pm SE & SD & Range & Mean \pm SE & SD & Range \\
\hline \multirow[t]{5}{*}{ Environmental parameters } & $\mathrm{WT}\left({ }^{\circ} \mathrm{C}\right)$ & $23.7 \pm 0.6$ & 3.2 & 14.0 & $23.7 \pm 0.6$ & 3.3 & 13.9 \\
\hline & $\mathrm{DO}\left(\mathrm{mg} \mathrm{L}^{-1}\right)$ & $7.2 \pm 0.5$ & 2.7 & 13.4 & $8.1 \pm 0.4$ & 0.4 & 2.5 \\
\hline & Cond. $\left(\mu \mathrm{S} \mathrm{cm}^{-1}\right)$ & $241.5 \pm 24.1$ & 138.9 & 598.3 & $244.7 \pm 24.5$ & 140.7 & 591.0 \\
\hline & Tur. (NTU) & $10.2 \pm 2.0$ & 12.0 & 50.4 & $11.7 \pm 2.6$ & 15.2 & 74.0 \\
\hline & Chl. $a\left(\mu \mathrm{g} \mathrm{L}^{-1}\right)$ & $15.5 \pm 1.6$ & 9.1 & 35.0 & $19.4 \pm 1.8$ & 10.1 & 36.7 \\
\hline \multirow[t]{2}{*}{ Asplanchna } & A. priodonta & $2.6 \pm 0.8$ & 4.6 & 17.5 & $65.7 \pm 19.7$ & 112.9 & 354.0 \\
\hline & A. herrickii & - & - & - & $15.4 \pm 11.0$ & 63.1 & 343.8 \\
\hline \multirow[t]{7}{*}{ Pelagic rotifer } & Anuraeopsis & $25.0 \pm 2.1$ & 11.9 & 61.3 & $17.5 \pm 7.7$ & 44.2 & 192.5 \\
\hline & Ascomorpha & $21.3 \pm 0.6$ & 0.6 & 8.8 & $0.3 \pm 0.3$ & 1.5 & 8.8 \\
\hline & Brachionus & $41.7 \pm 6.7$ & 38.5 & 183.7 & $18.6 \pm 5.8$ & 33.5 & 131.3 \\
\hline & Filinia & $20.6 \pm 10.1$ & 57.9 & 332.5 & $2.7 \pm 2.1$ & 12.3 & 70.0 \\
\hline & Kelicottia & - & - & - & $0.8 \pm 0.8$ & 4.6 & 26.3 \\
\hline & Keratella & $47.6 \pm 24.1$ & 138.3 & 796.3 & $123.0 \pm 31.6$ & 181.7 & 953.8 \\
\hline & Polyarthra & $44.9 \pm 7.3$ & 42.0 & 192.5 & $67.9 \pm 14.1$ & 81.2 & 393.8 \\
\hline \multirow[t]{7}{*}{ Epiphytic rotifer } & Cephalodella & - & - & - & $1.9 \pm 1.4$ & 7.8 & 43.8 \\
\hline & Colurella & $26.9 \pm 2.2$ & 12.5 & 43.8 & $1.1 \pm 0.5$ & 2.9 & 8.8 \\
\hline & Euchlanis & $30.9 \pm 3.6$ & 20.4 & 105.0 & $1.9 \pm 0.6$ & 3.6 & 8.8 \\
\hline & Lepadella & $31.9 \pm 4.6$ & 26.4 & 131.3 & $2.1 \pm 0.9$ & 4.9 & 17.5 \\
\hline & Leacane & $37.2 \pm 4.7$ & 27.1 & 96.3 & $5.3 \pm 1.9$ & 10.7 & 52.5 \\
\hline & Testudinella & $27.2 \pm 1.7$ & 9.6 & 35.0 & $1.6 \pm 0.7$ & 4.1 & 17.5 \\
\hline & Trichotria & $49.2 \pm 10.8$ & 62.3 & 323.8 & $19.4 \pm 5.0$ & 28.5 & 122.5 \\
\hline Ambiguous rotifer & Mytilina & $33.5 \pm 5.9$ & 34.1 & 175.0 & $2.7 \pm 1.2$ & 6.7 & 26.3 \\
\hline \multirow[t]{2}{*}{ Crustacean } & Cladocerans & $25.4 \pm 4.2$ & 24.3 & 105.0 & $12.6 \pm 4.6$ & 26.4 & 140.0 \\
\hline & Copepods & $25.6 \pm 3.8$ & 21.8 & 105.0 & $12.2 \pm 2.2$ & 12.5 & 35.0 \\
\hline
\end{tabular}

WT, water temperature; DO, dissolved oxygen; Cond., conductivity; Tur., turbidity; Chl. a, chlorophyll a.

Tab. 2. One-way nested ANOVA results for the effects of main groups (shown as Habitat in the table: vegetated- and open water zone) and subgroups (i.e., shown as Sampling point) on environmental parameters, two Asplanchna species, and other rotifers (both pelagic and epiphytic).

\begin{tabular}{|c|c|c|c|c|c|c|}
\hline Type & Source of data & Component of variance & df & Residual df & F & $\mathbf{P}$ \\
\hline \multirow[t]{10}{*}{ Environmental parameters } & WT $\left({ }^{\circ} \mathrm{C}\right)$ & Habitat & 1 & 192 & 0.11 & 0.95 \\
\hline & & Sampling point & 4 & 192 & 0.20 & 0.91 \\
\hline & $\mathrm{DO}\left(\mathrm{mg} \mathrm{L}^{-1}\right)$ & Habitat & 1 & 192 & 3.03 & 0.07 \\
\hline & & Sampling point & 4 & 192 & 0.04 & 0.99 \\
\hline & Cond. $\left(\mu \mathrm{S} \mathrm{cm}^{-1}\right)$ & Habitat & 1 & 192 & 0.19 & 0.93 \\
\hline & & Sampling point & 4 & 192 & 0.07 & 0.98 \\
\hline & Tur. (NTU) & Habitat & 1 & 192 & 0.49 & 0.78 \\
\hline & & Sampling point & 4 & 192 & 0.05 & 0.98 \\
\hline & Chl. $a\left(\mu \mathrm{g} \mathrm{L}^{-1}\right)$ & Habitat & 1 & 192 & 2.94 & 0.09 \\
\hline & & Sampling point & 4 & 192 & 0.35 & 0.86 \\
\hline \multirow[t]{2}{*}{ Asplanchna } & A. priodonta & Habitat & 1 & 102 & 32.16 & 0.00 \\
\hline & & Sampling point & 4 & 102 & 0.31 & 0.88 \\
\hline \multirow[t]{6}{*}{ Rotifer } & Total rotifer & Habitat & 1 & 192 & 2.47 & 0.18 \\
\hline & & Sampling point & 4 & 192 & 0.05 & 0.98 \\
\hline & Pelagic rotifer & Habitat & 1 & 192 & 1.61 & 0.41 \\
\hline & & Sampling point & 4 & 192 & 0.01 & 0.99 \\
\hline & Epiphytic rotifer & Habitat & 1 & 192 & 240.34 & 0.00 \\
\hline & & Sampling point & 4 & 192 & 0.06 & 0.97 \\
\hline
\end{tabular}

df, degree of freedom; WT, water temperature; DO, dissolved oxygen; Cond., conductivity; Tur., turbidity; Chl. a, chlorophyll a. 
259; A. herrickii, 58) revealed that the two Asplanchna species had different diets in the study sites (Fig. 3). Asplanchna priodonta consumed more diverse prey to $A$. herrickii, and rotifers, phytoplankton, and protozoa were found from $A$. priodonta's guts. In contrast, $A$. herrickii consumed only Euglena; no other prey items were found. In the case of rotifer predation by $A$. priodonta, this predator consumed primarily Keratella and Polyarthra, even though Polyarthra, Keratella, and Trichotria (sorted by relative frequency) were the most frequent species at the study sites (Fig. 4).

Regression analysis (Fig. 5) clearly showed the relationships between average densities of $A$. priodonta and the prey rotifer species in the water (pelagic, epiphytic, Keratella, and Polyarthra, respectively). A power function generated the highest determination coefficient (Tab. 4). Pelagic rotifers in vegetated zones were not correlated to A. priodonta density, but they were negatively correlated

Tab. 3. Summary of stepwise multiple regression aimed to predict density of $A$. priodonta (response variable) with respect to environmental parameters (explanatory variables) in open water zones. Data were transformed prior to analyses using either the arcsine-square root (proportion agricultural land) or log (all other variables) transformation.

\begin{tabular}{lccc}
\hline Explanatory variables & $\mathrm{B}_{\mathrm{j}}$ & $t$ & $\mathrm{P}$ \\
\hline Constant & 49.327 & 1.823 & 0.079 \\
Area $\left(\mathrm{m}^{2}\right)$ & 0.015 & 11.115 & 0.000 \\
Pelagic rotifer density (ind. $\left.\mathrm{L}^{-1}\right)$ & -0.125 & -2.222 & 0.035 \\
\hline
\end{tabular}

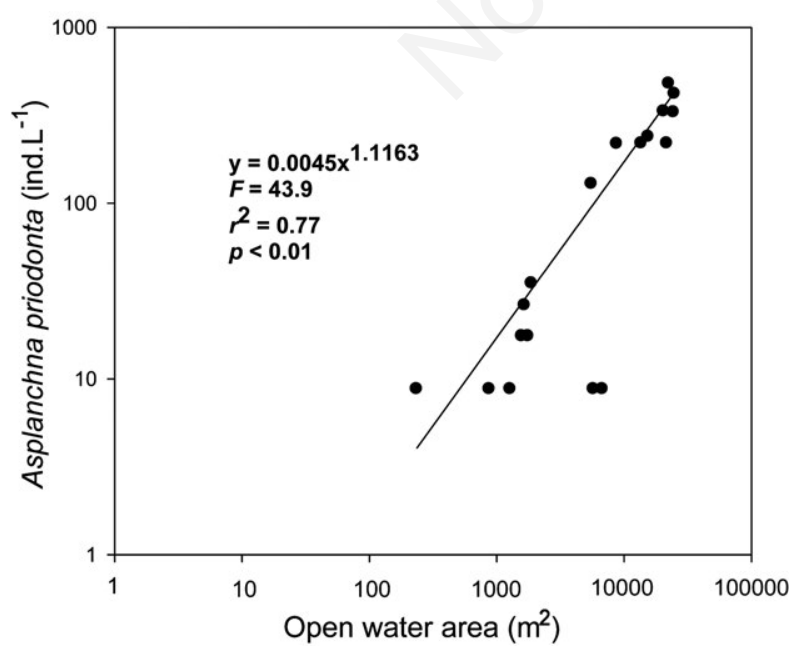

Fig. 2. The relationship between the area of open water zones and the density of Asplanchna priodonta $(\mathrm{n}=18$; regression df, 1; residual df, 16).

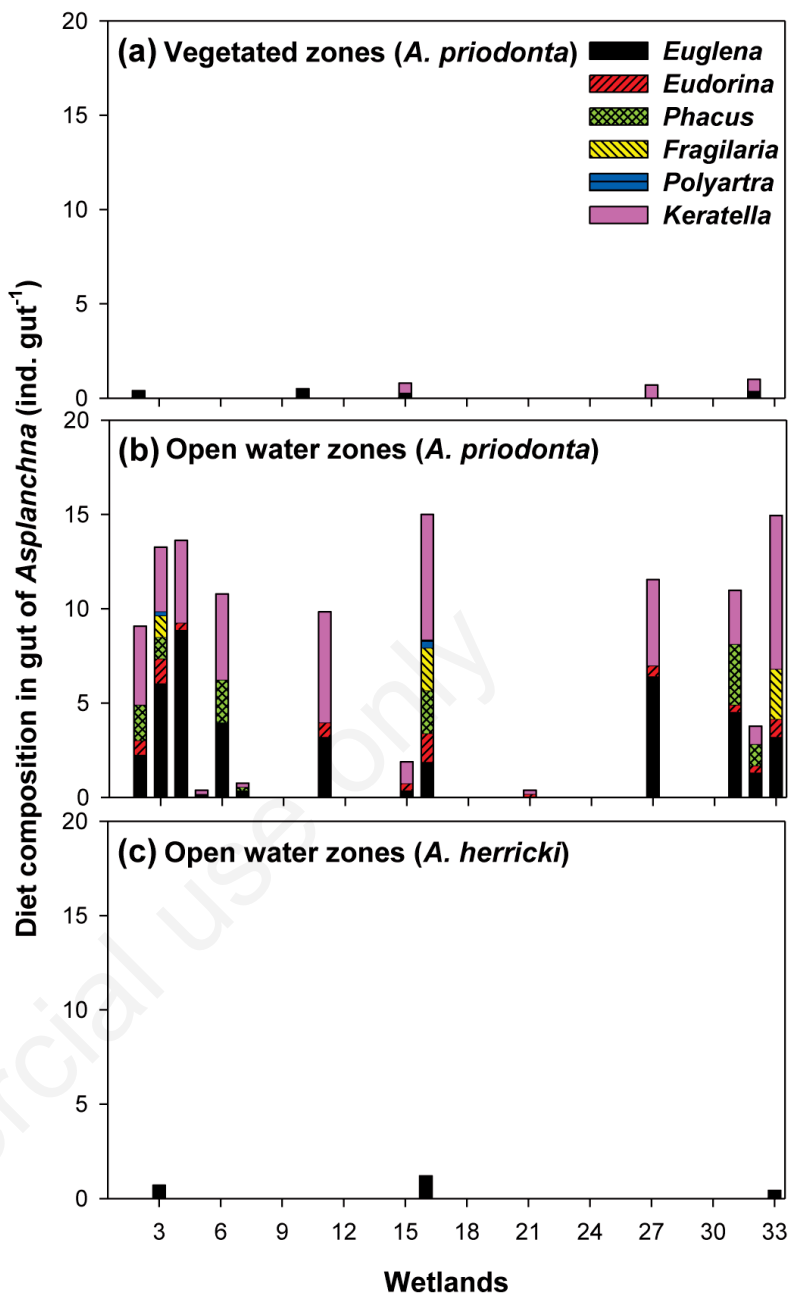

Fig. 3. Gut content of Asplanchna priodonta and Asplanchna herrickii in vegetated and open water zones.

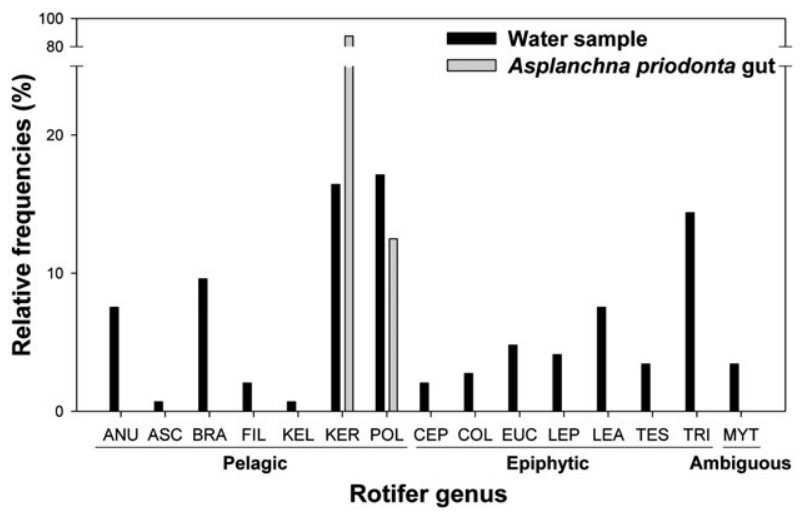

Fig. 4. Relative frequencies (\%) of prey rotifer genera in wetland water samples and Asplanchna priodonta gut contents. ANU, Anuraeopsis; ASC, Ascomorpha; BRA, Brachionus; FIL, Filinia; KEL, Kelicottia; KER, Keratella; POL, Polyarthra; CEP, Cephalodella; COL, Colurella; EUC, Euchlanis; LEP, Lepadella; LEA, Leacane; TES, Testudinella; TRI, Trichotria; MYT, Mytilina. 
with the density of the predator $A$. priodonta in open water zones. The density of prey pelagic rotifers in open water declined as $A$. priodonta density increased (Fig. 5). Meanwhile, A. herrickii did not display any statistically significant correlation with prey rotifer density in open water zones (not shown in the figure). There was no significant correlation between epiphytic rotifers and the density of either of the two Asplanchna species, in both vegetated and open water zones. Among prey rotifer genera, Keratella and Polyarthra displayed negative correlation with A. priodonta density (Fig. 5 c,d). Fig. 6 illustrates the relationships between prey density (Keratella spp. and Polyarthra spp.) in water samples and in the gut contents of Asplanchna. The density of Keratella in the water samples was strongly negatively correlated to the number of Keratella trophi in Asplanchna guts. However, Polyarthra did not show any statistically significant relationship.

\section{DISCUSSION}

\section{Influence of macrophytes on Asplanchna and prey rotifers}

Macrophytes are known to provide a suitable habitat and refuge for small animals (mainly zooplankton) in freshwater ecosystems (Castilho-Noll et al., 2010). This may explain the high density of rotifers observed in vegetated zones in the current study. The complex microhabitat structure provided by various macrophytes species hinders predator activity; therefore, they assist zooplankton in avoiding predators such as juvenile fish and macroinvertebrates (Dionne and Folt, 1991; Burks et al., 2006; Thomaz et al., 2008). In this scenario, it is to be expected that the density of prey rotifers in vegetated zones would be higher than that in open water. Predatory copepod as well as competitive cladoceran including Daphnia to rotifers (Gilbert, 1988; MacIsaac and Gilbert, 1989; Adrian
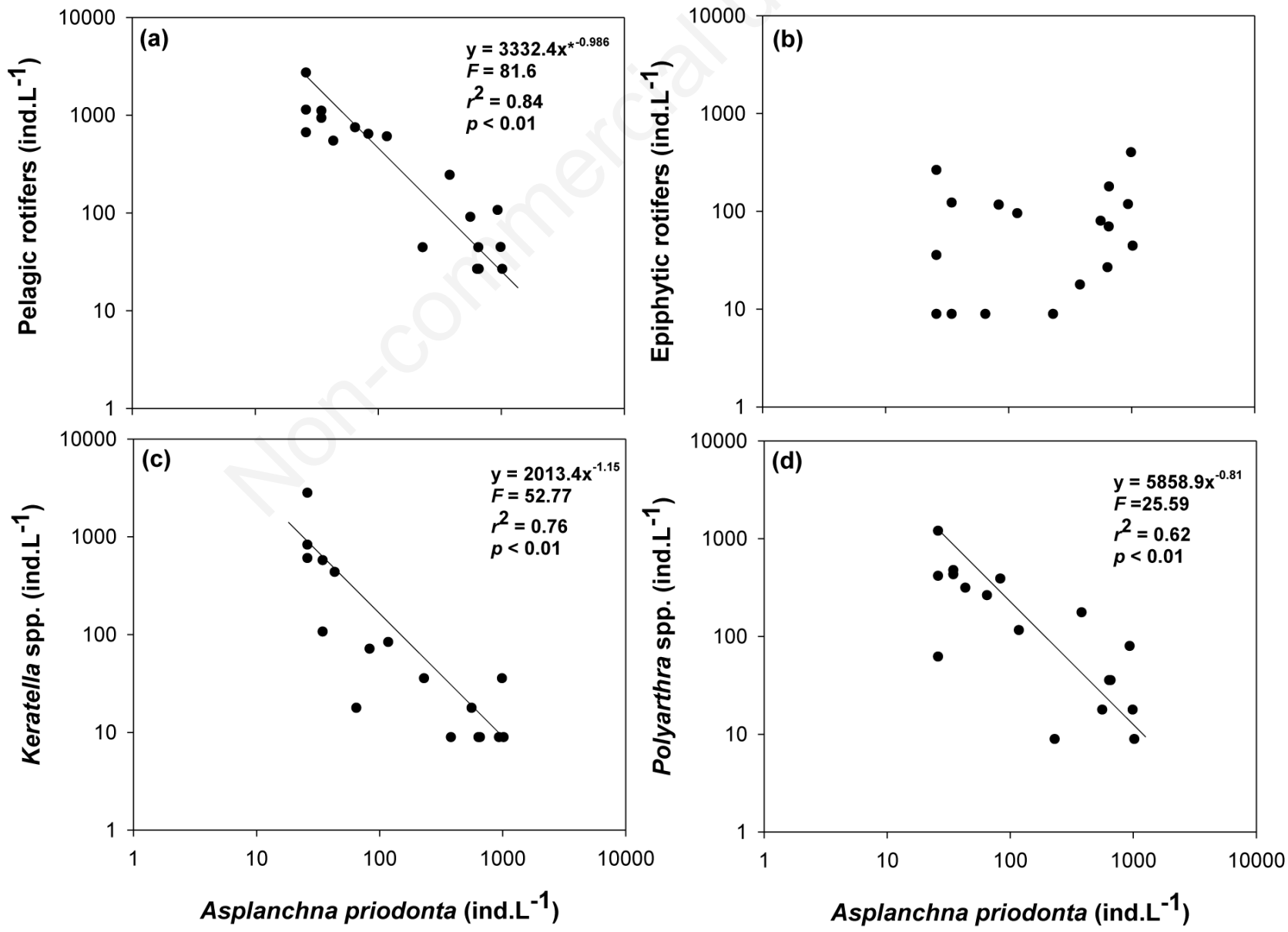

Fig. 5. The relationship between Asplanchna priodonta density and prey rotifers in open water zones (regression $\mathrm{df}=1, \mathrm{residual} \mathrm{df}=16$ ). (a) Prey pelagic rotifers; (b) prey epiphytic rotifers; (c) Keratella spp. in water samples; and (d) Polyarthra spp. in water samples. n=18 for each panel. 
and Frost, 1993; Brandl, 2005; Diéguez and Gilbert, 2011) rarely appeared in the vegetated zones of the study sites, which might affect larger density of prey rotifers in the vegetated zones.

In our study, macrophytes supported a relatively high abundance of epiphytic rotifers, but this was not the case for pelagic rotifers. Epiphytic rotifers can attach to substrates (such as the stems and leaves of macrophytes) in complex microhabitats (Brönmark, 1985; Choi et al., 2014); Asplanchna is not an effective predator of such rotifers. For this reason, vegetated zones are an unfavourable habitat for Asplanchna. As observed in our study, the prey rotifers preferred by Asplanchna include the pelagic rotifers Keratella and Polyarthra, which were abundant in open water zones. In addition, open water zones with large areas encouraged the proliferation of $A s$ planchna. Under these circumstances, it is advantageous for Asplanchna to occupy a habitat characterised by the presence of an abundant food source. Therefore, macrophytes are a very important factor affecting the distribution of rotifers, with consequent effects on the distribution of Asplanchna. Although a higher density of rotifers was observed in vegetated zones than in open water zones, the relationship between this condition and Asplanchna density is unclear. One possible hypothesis is regarding scarce feeding activity of Asplanchna in vegetated zones. Relationship discovery between vegetation and predatory $A s$ planchna should be addressed in further research in order to examine food web structure and function more exactly.

In result of the stepwise multiple regression, the density of $A$. priodonta displayed strong relationship with the area of open water zones and the density of pelagic rotifers. Exclusion of other environmental parameters would be due to relatively smaller variation of the parameters among the study sites. It is expected that the sampling was conducted within short period to minimize seasonal variation of the investigated parameters, therefore, relatively more constantly maintained parameters would be recognized as responsible variable to the changes of $\mathrm{A}$. priodonta. Kappes et al. (2000) suggested that seasonal changes of Asplanchna was depending on water temperature variation, however, in this study, the temperature variation was not large enough to bring out variation of Asplanchna density.

Tab. 4. Results of various types of simple regression analyses. The applications were aimed to investigate: i) influence of $A$. priodonta on different types of prey rotifer; ii) relationship between densities of prey rotifer observed in field and $A$. priodonta guts; and iii) relationship between densities of Keratella spp. observed in field and A. priodonta guts. For each comparison, five types of regression methods (linear, exponential, inverse, power, and logistic regressions) were adopted. Two degree of freedom (df) values are shown for each type of regression analysis, being the first the regression df and the second the residual df.

\begin{tabular}{|c|c|c|c|c|c|c|c|}
\hline \multicolumn{2}{|c|}{ Variables } & \multirow[t]{2}{*}{ Value } & \multicolumn{5}{|c|}{ Types of regression } \\
\hline Explanatory & Response & & Linear & Exponential & Inverse & Power & Logistic \\
\hline \multirow[t]{16}{*}{ A. priodonta } & Pelagic rotifer & df & 1,16 & 1,16 & 1,16 & 1,16 & 1,16 \\
\hline & & $F$ & 11.83 & 41.56 & 30.48 & 81.64 & 41.57 \\
\hline & & $r^{2}$ & 0.42 & 0.72 & 0.66 & 0.84 & 0.72 \\
\hline & & $\mathrm{P}$ & 0.00 & 0.00 & 0.00 & 0.00 & 0.00 \\
\hline & Epiphytic rotifer & df & 1,16 & 1,16 & 1,16 & 1,16 & 1,16 \\
\hline & & $F$ & 2.34 & 3.41 & 0.19 & 2.04 & 3.41 \\
\hline & & $r^{2}$ & 0.13 & 0.18 & 0.01 & 0.11 & 0.18 \\
\hline & & $\mathrm{P}$ & 0.15 & 0.83 & 0.67 & 0.17 & 0.08 \\
\hline & Keratella spp. & df & 1,16 & 1,16 & 1,16 & 1,16 & 1,16 \\
\hline & & $F$ & 3.48 & 18.49 & 14.66 & 52.77 & 18.49 \\
\hline & & $r^{2}$ & 0.18 & 0.54 & 0.48 & 0.76 & 0.54 \\
\hline & & $\mathrm{P}$ & 0.81 & 0.00 & 0.00 & 0.00 & 0.00 \\
\hline & Polyarthra spp. & $\mathrm{df}$ & 1,16 & 1,16 & 1,16 & 1,16 & 1,16 \\
\hline & & $F$ & 8.09 & 18.32 & 15.79 & 18.32 & 18.32 \\
\hline & & $r^{2}$ & 0.34 & 0.53 & 0.50 & 0.62 & 0.53 \\
\hline & & $\mathrm{P}$ & 0.01 & 0.00 & 0.00 & 0.00 & 0.00 \\
\hline \multirow[t]{4}{*}{ Prey rotifer in field } & Prey rotifer in gut & df & 1,16 & 1,16 & 1,16 & 1,16 & 1,16 \\
\hline & & $F$ & 18.50 & 39.69 & 11.38 & 58.71 & 39.69 \\
\hline & & $r^{2}$ & 0.54 & 0.71 & 0.42 & 0.79 & 0.71 \\
\hline & & $\mathrm{P}$ & 0.00 & 0.00 & 0.00 & 0.00 & 0.00 \\
\hline \multirow[t]{4}{*}{ Keratella spp. in field } & Keratella spp. in gut & df & 1,16 & 1,16 & 1,16 & 1,16 & 1,16 \\
\hline & & $F$ & 23.63 & 58.67 & 35.24 & 98.81 & 58.67 \\
\hline & & $r^{2}$ & 0.60 & 0.79 & 0.69 & 0.86 & 0.79 \\
\hline & & $\mathrm{P}$ & 0.00 & 0.00 & 0.00 & 0.00 & 0.00 \\
\hline
\end{tabular}


Even though there are some studies that have tried to distinguish rotifer into different habitat groups, there is still arguments about the separation. As shown in Supplementary Tab. 1, some species are under ambiguity. If precise information about the functional role of the ambiguous species is available, the interaction between prey rotifer and the predator (in this study, Asplanchna) will be more clearly understood.

\section{Food source differentiation among Asplanchna species}

We observed that the diet composition of the two predator species (A. priodonta and A. herrickii) examined in this study differed from each other. The former utilised both rotifers and phytoplankton and was therefore omnivorous. In contrast, the latter relied primarily on Euglena, mirroring what was reported by Chang et al. (2010). However, the greater dependency of $A$. herrickii on detritus may be explained by the hypothesis of Kappes et al. (2000) and Pociecha and Wilk-Wozniak (2008). The morphotypes and trophi morphology of Asplanchna have been suggested as important factors influencing speciesspecific feeding habits (Hampton and Starkweather, 1998). Asplanchna priodonta and A. herrickii have very similar rami morphologies (Jersabek et al., 2003), but $A$. priodonta has more sharpened rami tips than $A$. herrickii. Relatively inefficient trophi morphology for active predation might lead the species to consume more diverse food items. Based on the above, Asplanchna species may exhibit species-specific feeding habits, and different species may play different ecological roles in the freshwater food web. Furthermore, food differentiation be- tween the two Asplanchna species examined may reduce competition, leading to their mutual coexistence. In our study, $A$. herrickii was observed only at the three wetlands with the largest areas of open water. In addition, these wetlands were characterised by highly turbid water, a low density of prey rotifers, and low chlorophyll $a$ concentration. The observed environmental conditions (i.e., the presence of sufficient detritus) in those wetlands may be suitable for the growth and development of $A$. herrickii, but this requires further assessment.

\section{Prey preference of Asplanchna spp.}

Most predators experience difficulties in finding their preferred prey, which become scarce due to intensive elimination (O’Donoghue et al., 1997). Generally, the feeding behaviour of Asplanchna depends on the rate at which they encounter food/prey sources in open water. Conde-Porcuna and Sarma (1995) confirmed that Asplanchna increased its consumption of prey species that were present at high densities, and attributed this phenomenon to an increased rate of predator-prey encounters, despite the fact that the presence of Asplanchna induces activation of certain protective mechanisms in prey rotifers (Iyer and Rao, 1995; 1996). In this study, Polyarthra and Keratella, which were largely consumed by $A$. priodonta, were the most frequent species in all of the examined wetlands during the study period (i.e., open water zones). Gilbert (1985) suggested that Polyarthra exhibits effective escape mechanisms, such as rapid jumping movements, to avoid predators. This may explain why Polyarthra was less likely to be consumed than Keratella
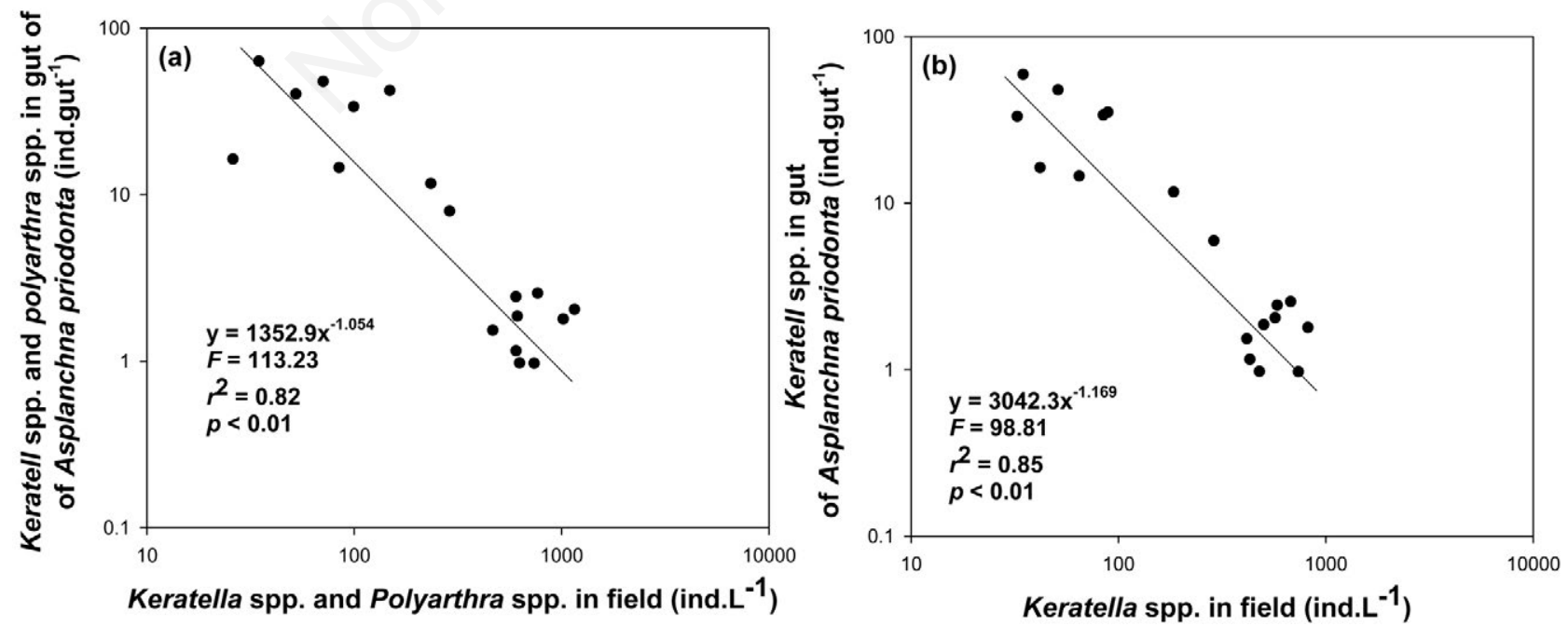

Fig. 6. The relationship between prey items (Keratella spp. and Polyarthra spp.) in the water samples and those in the gut contents of Asplanchna priodonta (regression df, 1; residual df, 16). (a) Density of two genera (summed) and number of trophi; (b) Keratella spp. density and its trophi number in the guts. $\mathrm{n}=18$ for each panel. 
in this study. We considered that Asplanchna utilises primarily rotifers; however, the results of this study revealed that Asplanchna spp. simultaneously consumed diverse food sources, such as phytoplankton and protozoa, as well as prey rotifers. However, prey rotifers were the dominant item. In a previous study, Asplanchna utilised rotifers early during the growing season when rotifers were abundant, and then shifted their consumption patterns by favouring phytoplankton and protozoa later in the season (Kappes et al., 2000). Chang et al. (2010) also reported that Asplanchna actively fed on rotifers in wetlands when the average water temperature was $18^{\circ} \mathrm{C}$, which may suggest that the period of this study was directly after the peak of rotifer consumption (Tab. 1; water temperature). The regression analyses of this study support the hypothesis that the density of prey rotifers (i.e., Keratella and Polyarthra) in water samples was negatively related to their consumption by Asplanchna, and that a shortage of prey rotifers encouraged the ingestion of phytoplankton (e.g., Eudorina, Fragilaria and Phacus) as alternative food sources; this was also indicated by Kappes et al. (2000). Asplanchna can feed on microscopic organisms, including bacteria, protozoa, and small rotifers (Iyer and Rao, 1996).

\section{CONCLUSIONS}

On the basis of our results, A. priodonta demonstrated preference for open water over vegetated zones. The two Asplanchna species examined in our study displayed different feeding habits. Open water zones were appropriate as habitat for Asplanchna because their food (mainly pelagic rotifers and phytoplankton) were more abundant in such zones. Additionally, the presence of a large area of open water supports a greater density of $A$. priodonta, and this relationship was also partially observed for $A$. herrickii in the three largest wetlands studied. These two Asplanchna species play different roles in the food web. With respect to the types of prey consumed, A. herrickii consumed primarily Euglena, whereas $A$. priodonta presented omnivorous character that consumed rotifers, phytoplankton, and protozoa. Asplanchna priodonta consumed only pelagic rotifer in open water, but had no effect on epiphytic rotifer densities. It can be expected that predation by Asplanchna may have an apparent impact on prey densities in open water zones. We conclude that the two aforementioned Asplanchna species play different roles in the food web, and that aquatic macrophytes significantly influence the distribution and feeding activity of Asplanchna.

\section{ACKNOWLEDGMENTS}

The authors are grateful to staff at the National Institute of Environmental Research, South Korea, and to students at the Pusan National University for collecting aquatic plant and zooplankton samples. We also appreciate two reviewers and the editor of the journal, for their valuable comments. This research was supported by the Korea National Long-Term Ecological Research (KNLTER).

\section{REFERENCES}

Adrian R, Frost TM, 1993. Omnivory in cyclopoid copepods: comparisons of algae and invertebrates as food for three, differently sized species. J. Plankton Res. 15:643-658.

Brandl Z, 2005. Freshwater copepods and rotifers: predators and their prey. Hydrobiologia 546:475-489.

Brönmark C, 1985. Interactions between macrophytes, epiphytes and herbivores: an experimental approach. Oikos 45:26-30.

Burkett V, Kusler J, 2000. Climate change: potentialimpacts and interactions in wetlands of the United States. J. Am. Water Resour. As. 36:313-320.

Burks RL, Mulderij G, Gross E, Jones I, Jacobsen L, Jeppesen E, Van Donk E, 2006. Center stage: the crucial role of macrophytes in regulating trophic interactions in shallow lake wetlands. Ecol. Stud. 191:37-59.

Castilho-Noll MSM, Câmara CF, Chicone MF, Shibata EH, 2010. Pelagic and littoral cladocerans (Crustacea, Anomopoda and Ctenopoda) from reservoirs of the Northwest of São Paulo State, Brazil. Biota Neotrop. 10:21-30.

Cazzanelli M, Warming TP, Christoffersen KS, 2008. Emergent and floating-leaved macrophytes as refuge for zooplankton in a eutrophic temperate lake without submerged vegetation. Hydrobiologia 605:113-122.

Chang KH, Doi H, Nishibe Y, Nakano S, 2010. Feeding habits of omnivorous Asplanchna: comparison of diet composition among Asplanchna herrickii, A. priodonta and A. girodi in pond ecosystems. J. Limnol. 69:209-216.

Choi JY, La GH, Jeong KS, Kim SK, Chang KH, Goo GJ, 2012. [Classification by zooplankton inhabit character and freshwater microbial food web: Importance of epiphytic zooplankton as energy source for high-level predator]. [Article in Korean]. Korean J. Limnol. 45:444-452.

Choi JY, Jeong KS, La GH, Kim SK, Goo GJ, 2014. Sustainment of epiphytic microinvertebrate assemblage in relation with different aquatic plant microhabitats in freshwater wetlands (South Korea). J. Limnol. 73:11-16.

Conde-Porcuna JM, Sarma SSS, 1995. Prey selection by Asplanchna girodi (Rotifera): the importance of prey defense mechanisms. Freshwater Biol. 33:341-348.

Diéguez MC, Gilbert JJ, 2011. Daphnia-rotifer interactions in Patagonian communities. Hydrobiologia 662:489-195.

Dionne M, Folt CL, 1991. An experimental analysis of macrophyte growth forms as fish foraging habitat. Can. J. Fish Aquat. Sci. 48:123-131.

Ferrari I, Farabegoli A, Mazzoni R, 1989. Abundance and diversity of planktonic rotifers in the Po River. Hydrobiologia 186:201-208.

Gilbert JJ, 1980. Feeding in the rotifer Asplanchna: behavior, cannibalism, selectivity, prey defenses, and impact on rotifer communities, p. 158-172. In: W.C. Kerfoot (ed.), Evolution and ecology of zooplankton communities. University Press of New England. 
Gilbert JJ, 1985. Escape response of the rotifer Polyarthra: a highspeed cinematographic analysis. Oecologia 66:322-331.

Gilbert JJ, 1988. Suppression of rotifer population by Daphnia: a review of the evidence, the mechanism, and the effects on zooplankton community structure. Limnol. Oceanogr. 33:1286-1303.

Guiset A, 1977. Stomach contents in Asplanchna and Ploesoma. Arch. Hydrobiol. Beih. 8:126-129.

Gyllström M, Hansson LA, Jeppesen E, García-Criado F, Gross E, Irvine K, Kairesalo T, Kornijow R, Miracle MR, Nykänen M, Nõges T, Romo S, Stephen D, Van Donk E, Moss B, 2005. Zooplankton community structure in shallow lakes: interaction between climate and productivity. Limnol. Oceanogr. 50:2008-2021.

Hampton SE, Starkweather PL, 1998. Differences in predation among morphotypes of the rotifer Asplanchna silvestrii. Freshwater Biol. 40:595-605.

Havel JE, Pattinson KR, 2004. Spatial distribution and seasonal dynamics of plankton in a terminal multiple-series reservoir. Lake Reserv. Manage. 20:14-26.

Horppila J, Eloranta P, Liljendahl-Nurminen A, Niemistö J, Pekcan-Hekim Z, 2009. Refuge availability and sequence of predators determine the seasonal succession of crustacean zooplankton in a clay-turbid lake. Aquat. Ecol. 43:91-103.

Hurlbert SH, 1984. Pseudoreplication and the design of ecological field experiments. Ecol. Monogr. 54:187-211.

Iyer N, Rao TR, 1995. Epizoic mode of life in Brachionus rubens Ehrenberg as a deterrent against predation by $A s$ planchna intermedia Hudson. Hydrobiologia 109:377-380.

Iyer N, Rao TR, 1996. Responses of the predatory rotifer $A s-$ planchna intermedia to prey species differing in vulnerability: laboratory and field studies. Freshwater Biol. 36: 512-533.

Jeppesen E, Jensen JP, Søndergaard M, Lauridsen T, Pedersen LJ, Jensen L, 1997. Top-down control in freshwater lakes: the role of nutrient state, submerged macrophytes and water depth. Hydrobiologia 342/343:151-164.

Jersabek CD, Segers H, Morris PJ, 2003. An illustrated online catalog of the Rotifera in the Academy of Natural Sciences of Philadelphia, ver. 1.0. Accessed on: 8 April 2003. Available from: http://rotifer.ansp.org/rotifer.php

Jeong KS, Kim DK, Joo GJ, 2007. Delayed influence of dam storage and discharge on the determination of seasonal proliferations of Microcystis aeruginosa and Stephanodiscus hantzschii in a regulated river system of the lower Nakdong River (South Korea). Water Res. 41:1269-1279.

Kappes H, Mechenich C, Shnsch U, 2000. Long-term dynamics of Asplanchna priodonta in lake windsborm with comments on the diet. Hydrobiologia 432:91-100.

Kuczynska-Kippen N, 2007. Habitat choice in rotifera commu- nities of three shallow lakes: impact of macrophyte substratum and season. Hydrobiologia 593:27-37.

Lack D, 1969. The numbers of bird species on islands. Bird Study 16:193-209.

MacIsaac HJ, Gilbert JJ, 1989. Competition between rotifers and cladocerans of different body sizes. Oecologia 81:295-301.

Mizuno T, Takahashi E, 1999. [An illustrated guide to freshwater zooplankton in Japan].[Book in Japanese]. Tokai University Press.

Nandini S, Perez-Chavez R, Sarma SSS, 2003. The effect of prey morphology on the feeding behaviour and population growth of the predatory rotifer Asplanchna sieboldi: a case study using five species of Brachionus (Rotifera). Freshwater Biol. 48:2131-2140.

O’Donoghue M, Boutin S, Krebs CJ, Hofer EJ, 1997. Numerical responses of coyotes and lynx to the snowshoe hare cycle. Oikos 80:150-162.

O’Hare MT, Baattrup-Pedersen A, Nijboer R, Szoszkiewicz K, Ferreira T, 2006. Macrophyte communities of European streams with altered physical habitat. Hydrobiologia 566:197-210.

Ortega-Mayagoitia E, Armengol X, Rojo C, 2000. Structure and dynamics of zooplankton in a semi-arid wetland, the National Park Las Tablas de Daimiel (Spain). Wetlands 20:629-638.

Pelicice FM, Agostinho AA, 2006. Feeding ecology of fishes associated with Egeria spp. patches in a tropical reservoir, Brazil. Ecol. Freshw. Fish 15:10-19.

Pociecha A, Wilk-Woznisk E, 2008. Comments on the diet of Asplanchna priodonta (Gosse, 1850) in the Dobczycki dam reservoir on the basis of field sample abservations. Oceanol. Hydrobiol. St. 37:63-69.

Sakuma M, Hanazato T, Nakazato R, Haga H, 2002. Methods for quantitative sampling of epiphytic microinvertebrates in lake vegetation. Limnology 3:115-119.

Schoeneck LJ, Wiliamson CE, Stroeckel ME, 1990. Diel periodicity and selectivity in the feeding rate of the predatory copepod Mesocyclops edax. J. Plankton Res. 12:29-40.

Simpson EH, 1949. Measurement of diversity. Nature 163:688.

Thatcher SJ, Daves CC, Gardner GA, 1993. Physical and chemical effects of macrograzers and micrograzers on enclosed, in situ phytoplankton in a Newfoundland lake. Hydrobiologia 250:127-141.

Thomaz SM, Dibble ED, Evangelista LR, Higuti J, Bini LM, 2008. Influence of aquatic macrophyte habitat complexity on invertebrate abundance and richness in tropical lagoons. Freshwater Biol. 53:358-367.

Wetzel RG, Likens GE, 2000. Limnological analyses. Springer: $429 \mathrm{pp}$.

Yamaji I, 1991. [Illustrations of the marine plankton of Japan]. [Book in Japanese]. Hoikusha Publ. Co. 